\title{
Moderate elevations of high-sensitivity cardiac troponin I and B-type natriuretic peptide in chronic hemodialysis patients are associated with mortality
}

Citation for published version (APA):

Geerse, D. A., Berkel, van, M., Vogels, S., Kooman, J. P., Konings, C. J. A. M., \& Scharnhorst, V. (2013). Moderate elevations of high-sensitivity cardiac troponin I and B-type natriuretic peptide in chronic hemodialysis patients are associated with mortality. Clinical Chemistry and Laboratory Medicine, 51(6), 1321-1328. https://doi.org/10.1515/cclm-2012-0305

DOI:

10.1515/cclm-2012-0305

Document status and date:

Published: 01/01/2013

Document Version:

Publisher's PDF, also known as Version of Record (includes final page, issue and volume numbers)

Please check the document version of this publication:

- A submitted manuscript is the version of the article upon submission and before peer-review. There can be important differences between the submitted version and the official published version of record. People interested in the research are advised to contact the author for the final version of the publication, or visit the $\mathrm{DOI}$ to the publisher's website.

- The final author version and the galley proof are versions of the publication after peer review.

- The final published version features the final layout of the paper including the volume, issue and page numbers.

Link to publication

\footnotetext{
General rights

- You may freely distribute the URL identifying the publication in the public portal. follow below link for the End User Agreement:

www.tue.nl/taverne

\section{Take down policy}

If you believe that this document breaches copyright please contact us at:

openaccess@tue.nl

providing details and we will investigate your claim.
}

Copyright and moral rights for the publications made accessible in the public portal are retained by the authors and/or other copyright owners and it is a condition of accessing publications that users recognise and abide by the legal requirements associated with these rights.

- Users may download and print one copy of any publication from the public portal for the purpose of private study or research.

- You may not further distribute the material or use it for any profit-making activity or commercial gain

If the publication is distributed under the terms of Article 25fa of the Dutch Copyright Act, indicated by the "Taverne" license above, please 
Daniël A. Geerse*, Miranda van Berkel, Steffie Vogels, Jeroen P. Kooman, Constantijn J.A.M. Konings and Volkher Scharnhorst

\section{Moderate elevations of high-sensitivity cardiac troponin I and B-type natriuretic peptide in chronic hemodialysis patients are associated with mortality}

\section{Abstract}

Background: Several biomarkers are associated with mortality in hemodialysis patients. In particular, elevated cardiac troponin $\mathrm{T}$ and B-type natriuretic peptide (BNP) are strong predictors of mortality; however, less is known about cardiac troponin I (cTnI). Elevated troponin I is detected in many hemodialysis patients, but the association of moderate elevations with mortality is unclear.

Methods: The relation between mortality and cTnI, using a high-sensitivity cTnI assay, as well as BNP and C-reactive protein (CRP) was evaluated in 206 chronic hemodialysis patients.

Results: Median follow-up was 28 months with a total mortality of $35 \%$. Mortality was significantly associated with elevated cTnI, BNP and CRP. Even patients with only moderate elevation of cTnI (0.01-0.10 $\mu \mathrm{g} / \mathrm{L})$ showed 2.5-fold increased mortality. Interestingly, hazard ratios for mortality for single (random) measurements were comparable to those for mean/median measurements. Subsequently, subgroup analysis based on combined markers was performed. Patients with both $\mathrm{cTnI}<0.01 \mu \mathrm{g} / \mathrm{L}$ and BNP in the first quartile had 100\% survival. Patients with either cTnI $<0.01 \mu \mathrm{g} / \mathrm{L}$ or BNP in the lowest quartile had significantly lower mortality (12\% and 13\%, respectively) than patients with BNP levels in the second quartile or higher and cTnI of $0.01-0.05 \mu \mathrm{g} / \mathrm{L}$ and patients with $\mathrm{cTnI} \geq 0.05$ $\mu \mathrm{g} / \mathrm{L}$ (mortality 46 and 58\%, respectively).

Conclusions: A combination of moderate elevation of $\mathrm{cTnI}$ and BNP provided additional prognostic value. A single measurement of these biomarkers performed comparably to the mean/median of multiple measurements.

Keywords: biomarker; B-type natriuretic peptide; hemodialysis; mortality; troponin.

*Corresponding author: Daniël A. Geerse, Department of Nephrology, Maastricht University Medical Centre, Postbus 5800, 6202 AZ, Maastricht, The Netherlands, E-mail: dgeerse@hotmail.com
Steffie Vogels and Jeroen P. Kooman: Department of Nephrology, Maastricht University Medical Centre, Maastricht, The Netherlands

Miranda van Berkel and Volkher Scharnhorst: Clinical Laboratory, Catharina Hospital, Eindhoven, The Netherlands Constantijn J.A.M. Konings: Department of Internal Medicine, Catharina Hospital, Eindhoven, The Netherlands

\section{Introduction}

Cardiovascular disease is the main cause of high mortality in hemodialysis patients. Several biochemical markers have been associated with mortality in dialysis patients. Elevations of cardiac troponins in asymptomatic hemodialysis patients are common, and elevated cardiac troponin $\mathrm{T}$ (cTnT) has been associated with increased (cardiovascular) mortality in multiple studies [1-8]. Less evidence exists for the relation between elevated cardiac troponin I (cTnI) and mortality in hemodialysis patients. Also, the prevalence of elevated cTnI was lower, as compared to cTnT [1, 9-11]. Elevated cTnI was associated with mortality in some [1, 12], but not all studies. Recently, a more sensitive cTnI assay has become available for the diagnosis of myocardial necrosis [13, 14]. The value of this test in hemodialysis patients is not clear, especially when moderate elevations of cTnI $(0.01-0.10 \mu \mathrm{g} / \mathrm{L})$ are found, which could not be measured in the past due to analytical variation in the assay.

B-type natriuretic peptide (BNP) and N-terminal proBNP (NT-proBNP) are used as markers for congestive heart failure and are associated with left ventricular hypertrophy and systolic dysfunction in the general population. Elevation of these markers is highly prevalent in hemodialysis patients and has been associated with increased mortality and cardiovascular death $[3,9,15]$. Elevation of BNP and NT-proBNP in hemodialysis patients not only reflects myocardial wall stress, but also decreased renal clearance. Although elevated BNP and NT-proBNP are 
thought to mainly reflect congestive heart failure and overhydration in dialysis patients, the increased cardiovascular mortality is only partially explained by the presence of left ventricular hypertrophy and systolic dysfunction [3, 16]. Moreover, there seems to be a complex interrelation with other biomarkers, such as troponin and C-reactive protein (CRP) [17].

Moderate elevations of CRP can be detected with high-sensitivity CRP tests. Mildly elevated levels of CRP are found in patients with chronic inflammation and have been associated with increased cardiovascular mortality in hemodialysis patients. Some studies report improved prognostic performance of these biomarkers when combined $[9,18]$, whereas others do not [3]. Within the multitude of different studies addressing cardiovascular biomarkers in hemodialysis patients, various combinations of biomarkers are used, as well as different analysis techniques and cut-off points. Also, biomarkers may have different prognostic performance for variable time frames [19].

The availability of these different biomarkers offers prognostic information that may be useful in various decision-making processes in hemodialysis patients, such as selecting patients for further cardiovascular screening in the pre-transplantation workup. The aim of the current study was to investigate the performance of high-sensitivity cTnI to predict mortality in asymptomatic hemodialysis patients and the interrelation of cTnI with the other commonly used biomarkers CRP and BNP.

\section{Materials and methods}

\section{Patients}

We prospectively included 206 chronic hemodialysis patients from the Catharina Hospital, Eindhoven, The Netherlands. The study was conducted according to the declaration of Helsinki and approved by the Medical Ethical Commission of Catharina Hospital according to Dutch law. All patients consented to the extra laboratory analyses, for which no extra blood sampling was required. Patients were eligible for inclusion if they were $\geq 18$ years of age and were on chronic hemodialysis treatment for $\geq 3$ months. Patients were included between May 2007 and May 2009 and were followed until January 2011 or until they stopped hemodialysis at our clinic. This was the case when they deceased, were transferred to another dialysis center or received a kidney transplant.

Patients were treated according to national quality guidelines, with a minimum frequency of three times per week for a duration of $4 \mathrm{~h}$ and a target $\mathrm{Kt} / \mathrm{V} \geq 1.2$ per session. Patient data were collected from the medical charts and laboratory data over the whole study period. Patient characteristics, comorbidities, cause of end-stage renal disease and cause of death were registered from the charts and from the national database. Patients with coronary disease were defined as patients with documented myocardial ischemia or coronary angiography showing significant coronary artery stenosis.

\section{Laboratory technique}

cTnI and BNP concentrations were measured on an Advia Centaur immunochemistry analyzer (Siemens Medical Solutions Diagnostics, Almere, The Netherlands) and CRP was measured on an Advia 1650 chemistry analyzer (Siemens Medical Solutions Diagnostics, Almere, The Netherlands) using the manufacturer's assay kits. The TnI-Ultra troponin kit from Siemens (reference 02790309) is a second-generation, high-sensitivity test with a $10 \% \mathrm{CV}$ at $0.05 \mu \mathrm{g} / \mathrm{L}$ and a cTnI concentration of $0.06 \mu \mathrm{g} / \mathrm{L}$ at the 99th percentile of a reference population [13]. CRP was measured with Wide range C-reactive protein kit from Siemens (ref 03108390), which is designed to measure CRP concentrations in the low range with high analytical precision (below $1 \mathrm{mg} / \mathrm{L}$ ). Imprecision was $3.5 \%$ at a CRP concentration of $0.8 \mathrm{mg} / \mathrm{L}$. The reference ranges for BNP (e.g., 95th percentile) for the mean age of our study population is $19.5 \mathrm{pmol} / \mathrm{L}$ for men and $21.1 \mathrm{pmol} / \mathrm{L}$ for women. At the level of $14 \mathrm{pmol} / \mathrm{L}$ imprecision is $3.5 \%$.

\section{Data collection}

Since the start of our study, our clinical laboratory was in possession of a new high-sensitivity cTnI assay. From that time, cTnI, BNP and CRP were added to the 3-monthly routine laboratory controls. The procedure of blood collection was in accordance with legal requirements and the ethical standards of the medical Ethical Commission of our institution. Blood samples were taken prior to hemodialysis every 3 months during the entire follow-up and laboratory analyses were performed within $2 \mathrm{~h}$ after collection of the samples. Patients were divided into subgroups according to cTnI, CRP and BNP concentrations. We created subgroups based on both serial and single measurements. For serial measurements, we used the mean of all measurements within a single patient for cTnI and the median for BNP and CRP, as the latter two did not have a normal distribution. For single measurements, we used the first measurement after inclusion. CTnI and CRP subgroups were made according to previously used cut-off points used for risk assessment [13]. cTnI cut-off values were $<0.01 \mu \mathrm{g} / \mathrm{L}, 0.01-0.05 \mu \mathrm{g} / \mathrm{L}, 0.05-0.10 \mu \mathrm{g} / \mathrm{L}$ and $>0.10 \mu \mathrm{g} / \mathrm{L}$. The first two groups are within the 99th percentile of a normal population; the value of $0.10 \mu \mathrm{g} / \mathrm{L}$ is the cut-off point for myocardial infarction at our hospital. Elevated BNP above the cut-off point for heart failure was present in almost all patients, so quartiles were defined for subgroup analysis, Q1: <44.4 pmol/L, Q2: 44.4-106.5 pmol/L, Q3: 106.5-222.1 pmol/L, Q4: >222.1 pmol/L. For CRP, three groups were defined (CRP $<1 \mathrm{mg} / \mathrm{L}, 1-3 \mathrm{mg} / \mathrm{L}$ and $>3 \mathrm{mg} / \mathrm{L}$ ) based on American Heart Association guidelines [20].

\section{Statistical analysis}

Statistical analysis was performed using Statistical Package for Social Sciences (SPSS) version 17.0 (SPSS Inc., Chicago, IL, USA). 
Variables were expressed as mean $\pm \mathrm{SD}$ or median with interquartile range (IQR). A paired sample t-test was used to evaluate the difference between single and multiple measurements of biomarkers. Survival analysis in different subgroups was done using Kaplan-Meier curves and Cox proportional hazard models, correcting for age and gender. A p-value $\leq 0.05$ was considered statistically significant.

\section{Results}

\section{Patient characteristics and general mortality}

Mean patient age at inclusion was $65.3 \pm 14.1$ years and 107 patients (51.9\%) were male. Further baseline characteristics are provided in Table 1 . Coronary artery disease was documented in 83 patients (40\%), 49 of which (24\%) had a history of myocardial infarction. Median follow-up was 28 months (range $0-45$ months). Within the study period, 72 of 206 patients died (35\%). One year after inclusion, mortality was $18 \%$.

\section{Mildly elevated values of cTnI, CRP and BNP are associated with cardiovascular and/or total mortality}

Cardiovascular and total mortality was assessed in patient subgroups divided according to the mean concentration of cTnI and median concentration of CRP and BNP on serial measurements during the entire study period. Patients with a history of coronary artery disease had significantly higher cTnI values (mean cTnI $0.15 \pm 0.36$ vs. $0.04 \pm 0.07 \mu \mathrm{g} / \mathrm{L}$ ). Cardiovascular and total mortality was significantly higher in patients with mean $\mathrm{cTnI}>0.10$ $\mu \mathrm{g} / \mathrm{L}$ as compared to patients with cTnI values $<0.05 \mu \mathrm{g} / \mathrm{L}$ (Figure 1A). Interestingly, patients with cTnI of 0.01-0.05 $\mu \mathrm{g} / \mathrm{L}$ and $0.05-0.10 \mu \mathrm{g} / \mathrm{L}$ already had a significantly higher (cardiovascular) mortality than patients with undetectable $\mathrm{cTnI}<0.01 \mu \mathrm{g} / \mathrm{L}$. Thus, even mild elevations of cTnI were associated with increased cardiovascular and total mortality.

Patients with median CRP $<1 \mathrm{mg} / \mathrm{L}$ had a significantly lower total mortality compared to patients with a $\mathrm{CRP}>3 \mathrm{mg} / \mathrm{L}$ ( $\mathrm{p}=0.009$ ). However, cardiovascular mortality showed no significant difference between these groups (Figure 1B), suggesting that increased CRP does not predict cardiovascular in hemodialysis patients.

Patients with a median BNP within the first quartile ( $<44.4 \mathrm{pmol} / \mathrm{L}$ ) had significantly lower (cardiovascular) mortality than those with higher BNP concentrations

\begin{tabular}{|c|c|}
\hline & $\mathrm{n}=206$ \\
\hline Mean age, years & $65.3 \pm 14.1$ \\
\hline Male sex & 107 (51.9\%) \\
\hline $\begin{array}{l}\text { Time on dialysis at start study, } \\
\text { months }\end{array}$ & 32 (range $3-357$ ) \\
\hline Diabetes mellitus & $77(37 \%)$ \\
\hline Coronary artery disease & $83(40 \%)$ \\
\hline History of myocardial infarction & $49(24 \%)$ \\
\hline Cerebrovascular disease & $45(22 \%)$ \\
\hline \multicolumn{2}{|l|}{$\begin{array}{l}\text { Cause of end stage renal } \\
\text { disease }\end{array}$} \\
\hline $\begin{array}{l}\text { Renal vascular disease } \\
\text { (excl. vasculitis) }\end{array}$ & $67(32.5 \%)$ \\
\hline Diabetic nephropathy & 39 (18.9\%) \\
\hline Glomerulonephritis & $29(14.0 \%)$ \\
\hline Interstitial nephritis & $21(10.2 \%)$ \\
\hline Multisystem disease & $18(8.7 \%)$ \\
\hline Cystic kidney disease & $12(5.8 \%)$ \\
\hline Others & $10(4.8 \%)$ \\
\hline Unknown & $7(3.3 \%)$ \\
\hline \multicolumn{2}{|l|}{ Cardiac troponin I (mean) } \\
\hline Median (IQR) of all patients & $\begin{array}{l}0.03 \mu \mathrm{g} / \mathrm{L} \\
(0.01-0.06 \mu \mathrm{g} / \mathrm{L})\end{array}$ \\
\hline$<0.01 \mu \mathrm{g} / \mathrm{L}$ & $59(28.6 \%)$ \\
\hline $0.01-0.05 \mu \mathrm{g} / \mathrm{L}$ & $94(45.6 \%)$ \\
\hline $0.05-0.10 \mu \mathrm{g} / \mathrm{L}$ & $28(13.6 \%)$ \\
\hline$>0.10 \mu \mathrm{g} / \mathrm{L}$ & $25(12.1 \%)$ \\
\hline \multicolumn{2}{|l|}{ C-reactive protein (median) } \\
\hline Median (IQR) of all patients & $\begin{array}{l}5.5 \mathrm{mg} / \mathrm{L} \\
(1.4-12.4 \mathrm{mg} / \mathrm{L})\end{array}$ \\
\hline$<1 \mathrm{mg} / \mathrm{L}$ & $41(19.9 \%)$ \\
\hline $1-3 \mathrm{mg} / \mathrm{L}$ & $35(17.0 \%)$ \\
\hline$>3 \mathrm{mg} / \mathrm{L}$ & $130(63.1 \%)$ \\
\hline \multicolumn{2}{|l|}{$\begin{array}{l}\text { B-type natriuretic peptide } \\
\text { (median) }\end{array}$} \\
\hline Median (IQR) of all patients & $\begin{array}{l}102.7 \mathrm{pmol} / \mathrm{L} \\
(44.4-222.1 \mathrm{pmol} / \mathrm{L})\end{array}$ \\
\hline 1st quartile (<44.4 pmol/L) & $51(24.8 \%)$ \\
\hline $\begin{array}{l}\text { 2nd quartile (44.4-106.5 } \\
\mathrm{pmol} / \mathrm{L})\end{array}$ & $52(25.2 \%)$ \\
\hline $\begin{array}{l}\text { 3rd quartile (106.5-222.1 } \\
\mathrm{pmol} / \mathrm{L})\end{array}$ & $52(25.2 \%)$ \\
\hline 4th quartile (>222.1 pmol/L) & $51(24.8 \%)$ \\
\hline
\end{tabular}

Table 1 Patient characteristics.

(Figure 1C). Patients with BNP levels in the second quartile did not differ significantly in (cardiovascular) mortality compared to those with BNP levels in the third quartile (concentration 44.4-106.6 pmol/L and 106.5-222.1 $\mathrm{pmol} / \mathrm{L}$, respectively). Both groups had significantly lower cardiovascular $(p=0.008)$ and total mortality $(p=0.002)$ than patients with BNP levels within the highest quartile (>222.1 pmol/L). Thus, in hemodialysis patients, even relatively mild elevations of BNP concentration ( $>44.4$ $\mathrm{pmol} / \mathrm{L}$ ) are associated with increased (cardiovascular) mortality. 


\section{The prognostic significance of random measurements of cTnI and BNP is comparable to the mean/median of serial measurements}

To investigate whether a first random measurement was equally well associated with mortality as the mean (cTnI) or median (CRP and BNP) of serial measurements, subgroups for both serial and single measurements of these biomarkers were analyzed. There was no significant difference between the values of single and multiple measurements. Kaplan-Meier survival plots for these subgroups were constructed for both serial and single measurements of these three biomarkers (Figure 2). Hazard ratios (HR) for mortality by Cox regression for mean/median measurements were comparable to those for single (random) measurements for CTnI, BNP and for CRP (Table 2), all p-values $>0.05$. Patients with a mean cTnI of 0.01-0.05 $\mu \mathrm{g} / \mathrm{L}$ had a mortality HR of 2.55 (95\% CI 1.05-6.21) compared to those with $\mathrm{cTnI}<0.01 \mu \mathrm{g} / \mathrm{L}$, whereas the HR was 2.83 (95\% CI 1.18-6.75) for a random cTnI measurement of $0.01-0.05 \mu \mathrm{g} / \mathrm{L}$. Patients with cTnI of $0.05-0.10 \mu \mathrm{g} / \mathrm{L}$ had a mortality HR of 3.57 (95\% CI 1.31-9.71) and 5.72 (95\% CI 2.19-14.93) for mean and random measurements, respectively. Patients with CRP of $1-3 \mathrm{mg} / \mathrm{L}$ had no significantly increased mortality for both mean and random measurements. Patients with BNP in the second quartile or higher had significantly increased mortality compared to patients with BNP in the first quartile. Again, this was the case for both single measurements and the median of serial measurements, and mortality HR were comparable. In conclusion, single measurements of cTnI and BNP had similar prognostic significance compared to the mean/median of serial measurements.

\section{Combined single measurement of cTnl and BNP offers additional prognostic information}

To improve the prognostic value of moderate elevations of cTnI and BNP, we created five subgroups based on combinations of single cTnI and BNP measurements. Subgroups were required to have enough patients and enough discriminative capacity with respect to total mortality. We constructed Kaplan-Meier survival curves for these subgroups (Figure 3). Patients with cTnI $<0.01 \mu \mathrm{g} / \mathrm{L}$ and BNP in the first quartile $(\mathrm{n}=7)$ had $100 \%$ survival. Patients with either cTnI $<0.01 \mu \mathrm{g} / \mathrm{L}$ or BNP in the lowest quartile (group 2 and 3) had significantly lower mortality (12\% and 13\%,
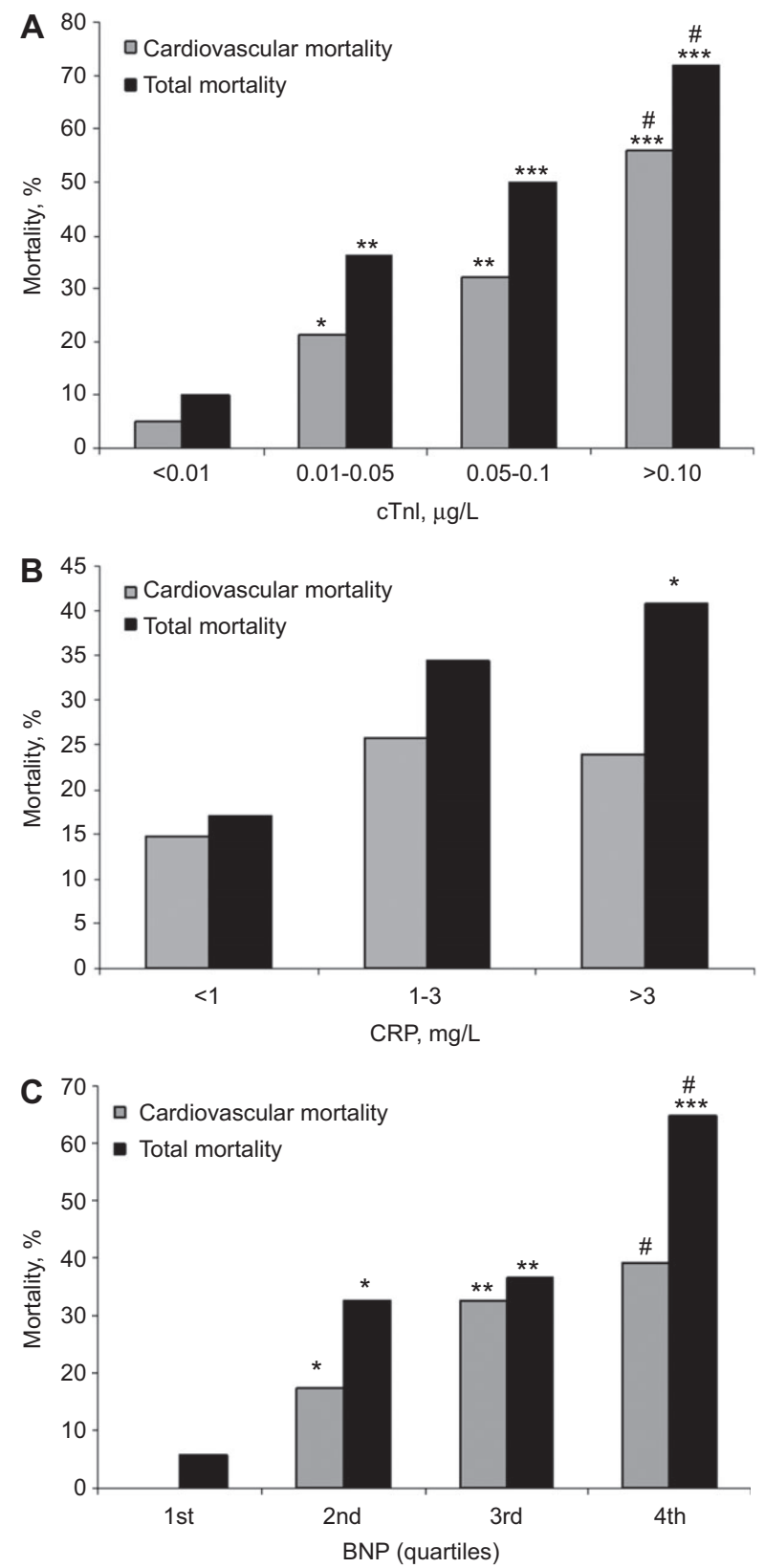

Figure 1 Cardiovascular and total mortality in subgroups divided by mean cardiac troponin I, mean C-reactive protein and median B-type natriuretic peptide values.

(A) Mean cardiac troponin I (cTnl): ${ }^{*} p<0.05,{ }^{* *} p<0.005$ and ${ }^{* \star *} \mathrm{p}<0.001 \mathrm{vs}$. $\mathrm{cTnl}<0.01 \mu \mathrm{g} / \mathrm{L}, \# \mathrm{p}=0.001$ vs. $\mathrm{cTnl} 0.01-0.05$ $\mu \mathrm{g} / \mathrm{L}$. (B) Mean C-reactive protein (CRP): ${ }^{*} \mathrm{p}<0.05$ vs. CRP $<1 \mathrm{mg} / \mathrm{L}$. (C) Median B-type natriuretic peptide (BNP): ${ }^{*} p<0.05,{ }^{\star *} p<0.005$ and ${ }^{* \star *} \mathrm{p}<0.001$ vs. BNP in the 1 st quartile (BNP $<44.4 \mathrm{pmol} / \mathrm{L}$ ). $\# p<0.05$ vs. BNP in the 2 nd quartile. Further between-group differences were not significant.

respectively) than patients with a BNP in the second quartile or higher and a cTnI of 0.01-0.05 $\mu \mathrm{g} / \mathrm{L}$ (group 4) and a $\mathrm{cTnI} \geq 0.05 \mu \mathrm{g} / \mathrm{L}$ (group 5) in which mortality was $46 \%$ and $58 \%$, respectively. At the end of the study period, mortality did not differ significantly between group 4 and $5(\mathrm{p}=0.065)$. 

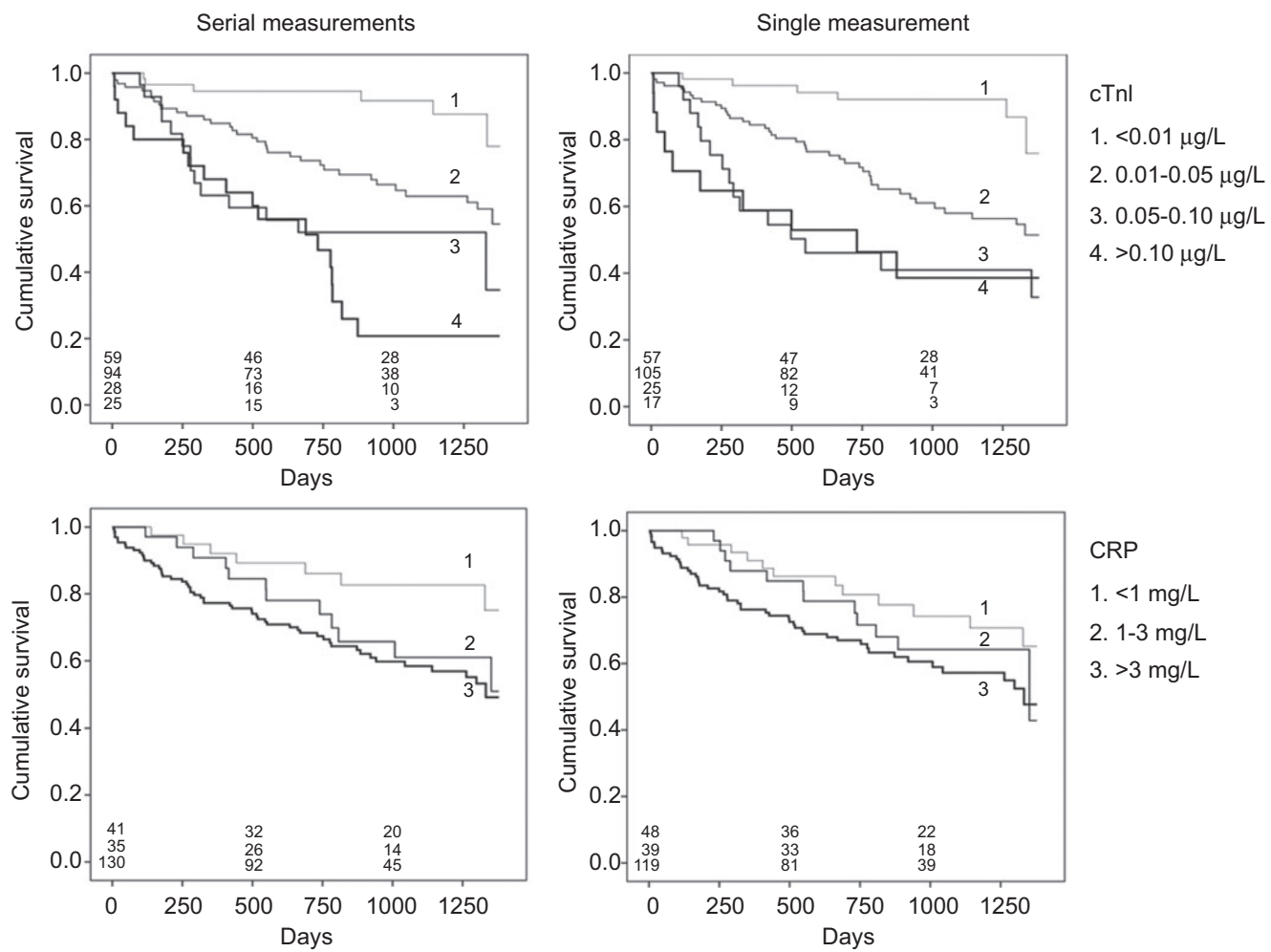

CRP

1. $<1 \mathrm{mg} / \mathrm{L}$

2. $1-3 \mathrm{mg} / \mathrm{L}$

3. $>3 \mathrm{mg} / \mathrm{L}$
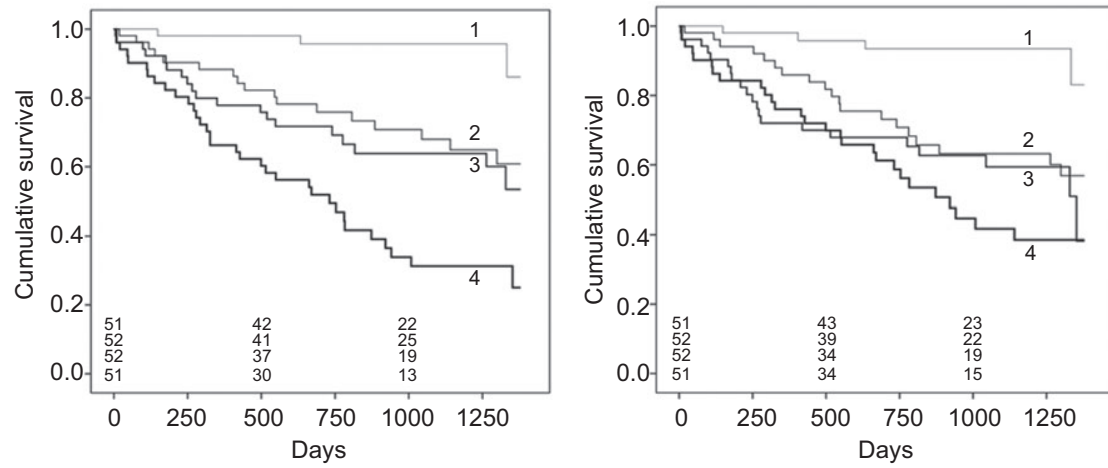

BNP

1. $<44.4 \mathrm{pmol} / \mathrm{L}$

2. $44.4-106.5 \mathrm{pmol} / \mathrm{L}$

3. $106.5-222.1 \mathrm{pmol} / \mathrm{L}$

4. $>222.1 \mathrm{pmol} / \mathrm{L}$

Figure 2 Kaplan-Meier survival curves for serial and single measurements of cardiac troponin I (cTnl), C-reactive protein (CRP) and B-type natriuretic peptide (BNP).

Left panel: serial measurements, subgroups divided by mean (cTnl) and median (CRP and BNP) values. Right panel: single measurements. Patient numbers at 0,500 and 1000 days are shown above the $x$-axis for consecutive subgroups.

\section{Discussion}

In this study, elevated cTnI, measured with a high-sensitivity assay, as well as BNP and CRP correlate with mortality. Moderate elevations of cTnI provided additional prognostic information, especially when combined with BNP. Furthermore, we found that a single measurement of these biomarkers performed comparably to the mean/ median of multiple measurements.

Although many studies report the association of cardiac troponin with mortality in asymptomatic hemodialysis patients, most studies use cTnT instead of cTnI and use a less sensitive assay with relatively high cut-off values. This study adds to the few studies on cTnI and demonstrates the additional prognostic information of moderate elevations of cTnI using a high-sensitivity assay. In previous studies, elevation of cTnI was found to be less prevalent than elevated CTnT in hemodialysis patients [1]. Diverse outcomes in previous studies addressing the association of cTnI with mortality were in part due to problems with the standardization of cTnI assays. One high-sensitivity cTnI assay has recently been studied in hemodialysis patients by Kumar et al. [11], but this study had a smaller group of patients with a shorter follow-up and mortality was not reported. Our current study shows that even moderate elevations of cTnI, even below or slightly higher than the 99th percentile 
$<0.01 \mu \mathrm{g} / \mathrm{L}$

$0.01-0.05 \mu \mathrm{g} / \mathrm{L}$

$0.05-0.10 \mu \mathrm{g} / \mathrm{L}$

$>0.10 \mu \mathrm{g} / \mathrm{L}$

cTnl (random)

$<0.01 \mu \mathrm{g} / \mathrm{L}$

$0.01-0.05 \mu \mathrm{g} / \mathrm{L}$

$0.05-0.10 \mu \mathrm{g} / \mathrm{L}$

$>0.10 \mu \mathrm{g} / \mathrm{L}$

CRP (median)

$<1 \mathrm{mg} / \mathrm{L}$

$1-3 \mathrm{mg} / \mathrm{L}$

$>3 \mathrm{mg} / \mathrm{L}$

CRP (random)

$<1 \mathrm{mg} / \mathrm{L}$

$1-3 \mathrm{mg} / \mathrm{L}$

$>3 \mathrm{mg} / \mathrm{L}$

BNP (median)

1st quartile

2nd quartile

3 rd quartile

4th quartile

BNP (random)

1st quartile

2nd quartile

3rd quartile

4th quartile
cTnl (mean)
HR

$95 \% \mathrm{Cl}$

1.05-6.21

1.31-9.71

2.43-16.59

1.18-6.75

2.19-14.93

1.87-14.85

$0.81-5.27$

$1.27-6.2$

$0.63-3.16$

1.02-3.65

1.38-16.26

1.50-17.69

3.12-34.26

1.00

4.03

4.77

5.83
$1.37-11.90$
$1.62-14.08$
$2.01-16.90$

0.005

0.001
Table 2 Association of serial (mean/median) and single (random) measurements of cTnl, CRP and BNP with mortality. Hazard ratios are adjusted for age and gender.

(0.01-0.05 $\mu \mathrm{g} / \mathrm{L}$ and $0.05-0.10 \mu \mathrm{g} / \mathrm{L}$, respectively), as measured with the Siemens TnI-Ultra assay are associated with higher mortality. These moderate elevations were found in $59.2 \%$ of patients in this study. In the study by Kumar et al. [11], 75\% of patients had stable cTnI values over time. Our study demonstrates that the mean cTnI of 3-monthly measurements show a similar correlation with mortality compared to a random (first) measurement. Consequently, repeated measurements may not be necessary for identifying high-risk patients, although reliable baseline values may be useful in diagnosing acute myocardial ischemia.

The previously found association between BNP and CRP with mortality is confirmed by our study results. BNP showed a stronger correlation with mortality than cTnI and CRP. In this study, as well as in others, elevated BNP was seen in the majority of hemodialysis patients, and cut-off values are not well-established for this patient group. Therefore, in this study we used quartiles of BNP values to define subgroups. As with cTnI, we compared the prognostic value of a single BNP measurement with the median of multiple 3-monthly measurements and found only a minor difference. Although elevated CRP was found in the majority of patients in our study and was associated with higher mortality, there was no additional value of CRP in multivariate analysis with BNP and cTnI.

Association of cTnI, BNP and CRP with total mortality was stronger than the association with cardiovascular mortality. The association with cardiovascular mortality of cTnI, BNP and CRP is thought to be explained by myocardial ischemia, myocardial wall stretch and chronic inflammation, respectively. For hemodialysis patients these relations are more complex and cTnI, BNP and CRP show a strong interrelation [17]. This is in line with the finding that in multivariate testing of these biomarkers CRP and cTnI lose statistical significance.

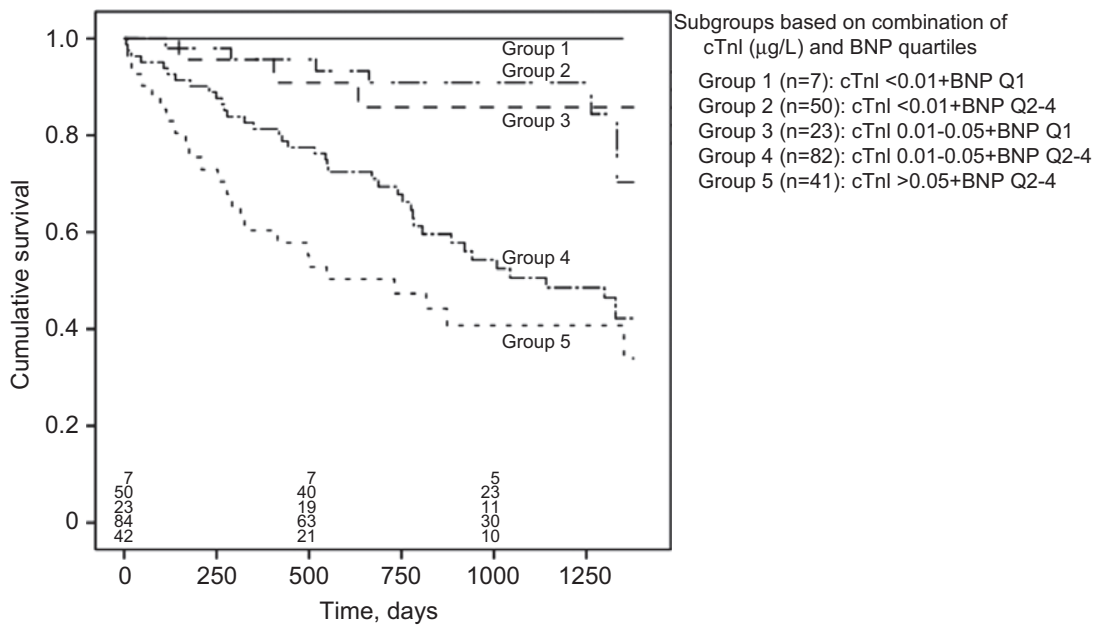

Figure 3 Kaplan-Meier survival curves for subgroups based on combination of cardiac troponin I (cTnI) and B-type natriuretic peptide (BNP) quartiles, based on single measurements.

BNP Q1, lowest quartile of BNP (BNP<44.4 pmol/L); BNP Q2-4, second quartile and higher (BNP $\geq 44.4 \mathrm{pmol} / \mathrm{L})$. There were no patients with cTnl $>0.05$ and BNP Q1. Patient numbers at 0,500 and 1000 days are shown above the $x$-axis for consecutive subgroups. 
Although BNP appears to be the best single predictor of mortality, combining BNP and cTnI gave additional prognostic information. Interestingly, after 2 year mortality was significantly higher in patients with BNP $\geq 44.4$ $\mathrm{pmol} / \mathrm{L}$ and $\mathrm{cTnI}$ 0.01-0.05 $\mu \mathrm{g} / \mathrm{L}$ as compared to patients with $\mathrm{cTnI} \geq 0.05 \mu \mathrm{g} / \mathrm{L}$, whereas this difference disappeared after the total follow-up period. This may reflect the lower number of patients included with a follow-up $>2$ years, but could also be explained by the fact that cardiac biomarkers can have different prognostic ability for different time frames. A time frame dependant difference between biomarkers was also reported by McGill et al. [19], where NT-proBNP was superior to cTnT after 30 months, but cTnT performed better after 47 months. We did not find a similar time dependant superiority of cTnI over BNP in our study.

There are some study limitations. First, this was a single center, observational study in a cohort of chronic hemodialysis patients. Coronary disease and cardiovascular mortality were documented from the charts. Other objective parameters for cardiovascular disease such as myocardial scintigraphy or echocardiography were not available for all patients.

Patients with either a cTnI $\geq 0.01 \mu \mathrm{g} / \mathrm{L}$ or a BNP $\geq 44.4$ $\mathrm{pmol} / \mathrm{L}$ had higher mortality than patients without elevation, but significantly lower mortality compared to patients with (moderate) elevation of both. This finding implies that a risk score of both markers could improve selection of patients at high risk for cardiovascular mortality.

Further studies are needed to address the possibility of such risk scores and to study the utilization of biochemical risk stratification for patients at high risk for cardiovascular events. This risk stratification may help to select patients for additional procedures such as coronary angiography and intervention.

\section{Conclusions}

Using a high-sensitivity cTnI assay, moderate elevations of cTnI were frequently found in chronic hemodialysis patients. Elevated cTnI, as well as BNP and CRP correlate with mortality. Moderate elevations of cTnI provided additional prognostic information, especially when combined with BNP. Patients with both $\mathrm{cTnI}<0.01 \mu \mathrm{g} / \mathrm{L}$ and BNP $<44.4 \mathrm{pmol} / \mathrm{L}$ had the lowest mortality. Patients with either a cTnI $\geq 0.01 \mu \mathrm{g} / \mathrm{L}$ or a BNP $\geq 44.4 \mathrm{pmol} / \mathrm{L}$ had intermediately increased mortality, whereas patients with elevation of both cTnI and BNP had the highest mortality.

Furthermore, we found that a single measurement of these biomarkers performed comparably to the mean/ median of multiple measurements.

\section{Conflict of interest statement}

Authors' conflict of interest disclosure: The authors stated that there are no conflicts of interest regarding the publication of this article. Research funding: None declared. Employment or leadership: None declared. Honorarium: None declared.

Received May 14, 2012; accepted November 9, 2012; previously published online December 10, 2012

\section{References}

1. Apple FS, Murakami MM, Pearce LA, Herzog CA. Predictive value of cardiac troponin I and $T$ for subsequent death in end-stage renal disease. Circulation 2002;106:2941-5.

2. Khan NA, Hemmelgarn BR, Tonelli M, Thompson CR, Levin A. Prognostic value of troponin $T$ and I among asymptomatic patients with end-stage renal disease: a meta-analysis. Circulation 2005;112:3088-96.

3. Satyan S, Light RP, Agarwal R. Relationships of N-terminal proB-natriuretic peptide and cardiac troponin $\mathrm{T}$ to left ventricular mass and function and mortality in asymptomatic hemodialysis patients. Am J Kidney Dis 2007;50:1009-19.

4. Hickman PE, McGill DA, Talaulikar G, Hiremagalur B, Bromley J, Rahman A, et al. Prognostic efficacy of cardiac biomarkers for mortality in dialysis patients. Intern Med J 2009;39:812-8.

5. Petrovic D, Obrenovic R, Stojimirovic B. Cardiac troponins and left ventricular hypertrophy in hemodialysis patients. Clin Lab 2008;54:145-52.
6. Sahinarslan A, Guz G, Okyay K, Mutluay R, Yalcin R, Bali M, et al. Prognostic value of troponin $T$ and homocysteine in patients with end-stage renal disease. Turk Kardiyol Dern Ars 2008;36:382-7.

7. Wang AY, Lai KN. Use of cardiac biomarkers in end-stage renal. disease. J Am Soc Nephrol 2008;19:1643-52.

8. Petrovic D, Stojimirovic BB. Cardiac troponins: outcome predictors in hemodialysis patients. J Artif Organs 2009;12:258-63.

9. Apple FS, Murakami MM, Pearce LA, Herzog CA. Multi-biomarker risk stratification of $\mathrm{N}$-terminal pro-B-type natriuretic peptide, high-sensitivity $\mathrm{C}$-reactive protein, and cardiac troponin $\mathrm{T}$ and $\mathrm{I}$ in end-stage renal disease for all-cause death. Clin Chem 2004;50:2279-85.

10. Jacobs LH, van de Kerkhof J, Mingels AM, Kleijnen VW, van der Sande FM, Wodzig WK, et al. Haemodialysis patients longitudinally assessed by highly sensitive cardiac troponin T and commercial cardiac troponin T and cardiac troponin I assays. Ann Clin Biochem 2009;46:283-90. 
11. Kumar N, Michelis MF, DeVita MV, Panagopoulos G, Rosenstock JL. Troponin I levels in asymptomatic patients on haemodialysis using a high-sensitivity assay. Nephrol Dial Transplant 2011;26:665-70.

12. Khan IA, Wattanasuwan N, Mehta NJ, Tun A, Singh N, Singh HK, et al. Prognostic value of serum cardiac troponin I in ambulatory patients with chronic renal failure undergoing long-term hemodialysis: a two-year outcome analysis. J Am Coll Cardiol 2001;38:991-8.

13. van de Kerkhof D, Peters B, Scharnhorst V. Performance of the Advia Centaur second-generation troponin assay TnI-Ultra compared with the first-generation cTnl assay. Ann Clin Biochem 2008;45:316-7.

14. Keller T, Zeller T, Peetz D, Tzikas S, Roth A, Czyz E, et al. Sensitive troponin I assay in early diagnosis of acute myocardial infarction. N Engl J Med 2009;361:868-77.

15. Madsen LH, Ladefoged S, Corell P, Schou M, Hildebrandt PR, Atar D. N-terminal pro brain natriuretic peptide predicts mortality in patients with end-stage renal disease in hemodialysis. Kidney Int 2007;71:548-54.
16. Zoccali C, Mallamaci F, Benedetto FA, Tripepi G, Parlongo S, Cataliotti A, et al. Cardiac natriuretic peptides are related to left ventricular mass and function and predict mortality in dialysis patients. J Am Soc Nephrol 2001;12:1508-15.

17. Jacobs LH, van de Kerkhof JJ, Mingels AM, Passos VL, Kleijnen VW, Mazairac AH, et al. Inflammation, overhydration and cardiac biomarkers in haemodialysis patients: a longitudinal study. Nephrol Dial Transplant 2010;25:243-8.

18. Hallen J, Madsen L, Ladefoged S, Fagerland MW, Serebruany VL, Agewall S, et al. Incremental value of a combination of cardiac troponin $\mathrm{T}, \mathrm{N}$-terminal pro-brain natriuretic peptide and C-reactive protein for prediction of mortality in end-stage renal disease. Scand J Urol Nephrol 2011;45:151-8.

19. McGill D, Talaulikar G, Potter JM, Koerbin G, Hickman PE. Over time, high-sensitivity InT replaces NT-proBNP as the most powerful predictor of death in patients with dialysis-dependent chronic renal failure. Clin Chim Acta 2010;411:936-9.

20. Ridker PM. Clinical application of C-reactive protein for cardiovascular disease detection and prevention. Circulation 2003;107:363-9. 